\title{
Remembering Gregg Schraw
}

\section{Matthew T. McCrudden ${ }^{1}$}

Published online: 3 November 2016

(C) Springer Science+Business Media New York 2016

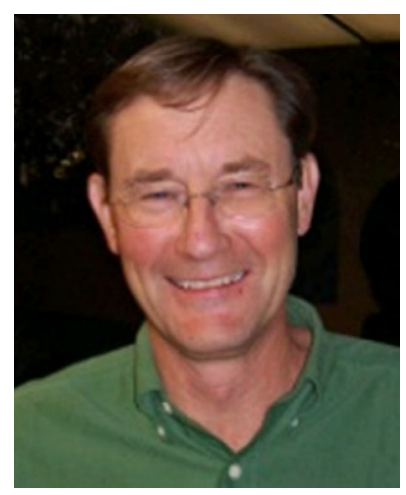

Gregg Schraw passed away on September 15, 2016 at age 62 after a battle with cancer. Gregg was a Barrick Distinguished Professor of educational psychology at the University of Nevada, Las Vegas (UNLV). He completed a bachelor's degree in secondary education and became a certified teacher. Later, he completed a M.S. in instructional science (1986), a M.S. in applied statistics (1988), and finally a Ph.D. in cognition and instruction, each from the University of Utah. The progression of his degrees was a prelude to a professional career that was characterized by his emphasis on the use of theory, design, and measurement to investigate practical issues in education.

Upon completing his Ph.D. in 1990, he accepted a position at the University of NebraskaLincoln and remained there until 2000, when he accepted a position at UNLV. He had a tremendous positive impact, professionally and personally, on those who interacted with him. His impact extended to colleagues and graduate students alike.

Gregg was a prolific scholar and an exceptionally versatile methodologist. He published over 100 research articles, book chapters, and edited books in the areas of human learning and

Matthew T. McCrudden

matt.mccrudden@vuw.ac.nz

1 Faculty of Education, Victoria University of Wellington, Wellington 6140, New Zealand 
testing. A distinguishing feature of his academic career was his ability to publish high-impact articles on multiple programs of research using quantitative, qualitative, and mixed methods. This is evidenced by his publication record across a range of topics, including but not limited to metacognition (e.g., Nietfeld and Schraw 2002; Schraw 2009; Schraw and Dennison 1994a; Schraw, Dunkle, and Bendixen 1995; Schraw and Moshman 1995), situational interest (e.g., Schraw, Bruning, and Svoboda 1995; Schraw and Lehman 2001), choice and learner engagement (e.g., Schraw, Flowerday, and Lehman 2001), student and teacher beliefs (e.g., Olafson and Schraw 2006), visual displays (e.g., Schraw, McCrudden, and Robinson 2013), academic procrastination (Schraw, Wadkins, and Olafson 2007), and text relevance (e.g., McCrudden and Schraw 2007; Schraw and Dennison 1994b). As can be seen in this list, he enjoyed pursuing multiple areas of research. This is ironic given that Gregg was a big fan of K. Anders Ericsson's work on expertise development (see Schraw 2005 for Gregg's interview of Ericsson), whose work reveals that experts focus their energies on toward a singular aim. Gregg encouraged his graduate students to also pursue multiple areas because he believed that peoples' interests likely change or diversify over their careers.

Gregg was very service oriented and viewed this as an essential contribution to the profession. He was an associate editor of the Journal of Educational Psychology and served on the editorial boards of Contemporary Educational Psychology, Applied Measurement in Education, Educational Psychologist, Educational Psychology Review, and Metacognition and Learning. In addition, he was recognized as a Fellow by the American Educational Research Association and contributed to the Graduate Student Mentoring Program. Clearly, he was a valued member of the research community.

Gregg taught courses in human cognition, statistics, human measurement, research methods, and evaluation. He was the recipient of several teaching and research awards, as well as the American Psychological Association's early career achievement award. He served for many years on the Nevada Department of Education's Technical Advisory Committee, which provides technical support for the state assessment programs, several Institute of Educational Science evaluation panels, and on the Technical Working Group for an evaluation of the National Assessment of Educational Progress.

Perhaps one of Gregg's most enduring contributions to the discipline was his ability to develop productive scholars. He used a blend of cognitive apprenticeship, a constructivist approach to learning, and deliberate practice to help his students maximize their knowledge and skills. Further, there was a bi-directional relationship between his research interests and those of his students. He welcomed students to become involved in his programs of research but also created space for them to pursue their own areas of interest. It should also be noted that he extended his mentoring to junior faculty members who were on the path to tenure. It is a testament to his collegiality and mentorship that many former graduate students came to visit, or reached out to him from afar, once word spread of his condition.

Gregg was an exceptionally hard worker, but he always had time for students and colleagues to stop by the office for a chat. Importantly, he was a devoted husband to Lori and father to Jeremy, Jacqueline, and Rob. He demonstrated how to balance family life with being a world class scholar. Although the last year of his life involved countless visits to the hospital as the cancer steadily advanced, he remained optimistic throughout. He was proud of his children's success and happy to see the arrival of his first grandchild.

In this tribute, a range of individuals were invited to provide contributions for remembering Gregg throughout his professional career. We organized the contributions chronologically 
beginning with Gregg's initial days as a graduate student at Utah, his time at Nebraska, and through to his time as a full professor at UNLV.

Gregg touched the lives of many people in educational psychology. He will be remembered for what he truly was - a great scholar, mentor, colleague, and friend.

\section{Matthew T. McCrudden, Associate Professor Victoria University of Wellington, New Zealand}

I knew Gregg was working that summer as a parking lot attendant so I went over to say hello. We were graduate students together at the University of Utah in the early to mid-1980s. I think the idea of doing research and possibly having an academic career was just becoming a realistic goal for both of us. We were lucky to have started at the same time that a couple of strong faculty members were getting their careers going in Utah. We had presented at AERA the year before. It had gone well. We had good support systems around us. I remember that it was a really hot day. Gregg was working in the lot by the Student Union. There was a shed out in the middle of the lot where he was assigned to sit through his shift. The lot was pretty empty. I looked in through the screen before saying anything. Gregg was seated in rapture with the largest trigonometry workbook I'd ever seen. He was so wrapped up into it that he had no idea someone was just standing there staring in at him. There was no air conditioning. It was hotter in that shed than it was out in the sun. Gregg had recently become motivated to get a Master's degree in math and statistics. To do this to the level of quality he wanted, he had to go back and work really hard to fill in all those needed high school and college math skills. No more than a year later he was showing me how to use and apply multivariate stats like spectral and cluster analysis. Gregg was wide open to learning. He gave freely to anyone around him what he knew. He did not want anything in return. Sharing a pizza and couple of beers was tops. Life was simple and good. My life has certainly been better for having Gregg in it, if even for a short time. I hope he knew how much he was loved.

\section{Rich Lapan, Professor}

\section{University of Massachusetts-Amherst}

Gregg and I were graduate students together at the University of Utah in the late 80s and early $90 \mathrm{~s}$ - he a couple of years ahead of me. We were fortunate to have faculty mentors who involved us early on in their research studies. Even better, we were given a lot of autonomy to design our own research studies, collect data, and analyze the results. This is how we developed our affinity and acumen for research. Gregg was at his happiest working on our research projects; I think we must have conducted at least ten different studies during these years as graduate students. Most of these studies were never published, but a few were Schraw, Trathen, Reynolds, and Lapan (1988); Burbules, Schraw, and Trathen (1989); Wade, Trathen, and Schraw (1990); and Schraw (1995). Working alongside him, I witnessed in Gregg an intelligence that was self-taught and a work ethic that was boundless, and I remember Gregg fondly as one of my mentors.

\section{Woody Trathen, Professor Appalachian State University}

Gregg was an undergraduate English major when I first met him. We were introduced by Penny Losse Gregersen, another English major who had enrolled in my undergraduate reading 
comprehension course. She thought Gregg and I had a lot in common so she arranged an informal meeting.

I knew Gregg was special even at that first casual meeting because we discussed topics ranging from Keats, to Emerson, to Bronowski, to the ACLU, and finally onto life as a scholar in academics. We never did get around to discussing reading comprehension. One seldom meets a person with Gregg's range and depth of knowledge, love of learning, and intellectual intensity. I asked Gregg if he had ever considered life as a scholar in higher education as our meeting time came to an end. When he said he had, I immediately offered him financial support if he would consider enrolling in my department's new doctoral program. That was the beginning of my 30+ year relationship with Gregg. As an aside, Dick Anderson had warned me before I left for my first academic position that insightful, intelligent, disciplined doctorallevel research assistants were very difficult to find, even at Illinois. Incredibly, I met one such student in Gregg reference in my second year as a professor.

Gregg's background in English meant that he had not taken the same preparatory courses that most future Educational Psychology scholars had taken. Consequently, there were some gaps in his initial knowledge base. Those gaps did not last long. In short order, Gregg became an excellent statistician, an expert at research design, an expert in the area of psychological learning theories, and an excellent science writer. His master's thesis in Statistics contributed original knowledge to that field as did his Educational Psychology doctoral dissertation, an incredible accomplishment for a young scholar.

It was never really appropriate to call Gregg a research assistant. I always considered him more of a colleague than a student. Virtually, all of the studies we did together were true collaborations. Our research generation process was simple. We would discuss a general idea and Gregg would ask a question or two, mostly about design or materials construction. Six weeks later, Gregg would return to my office with the completed data. After one year, he was generating and publishing studies completely on his own or working with other graduate students. I know few professors with faculty colleagues like that, much less doctoral students.

I chose to address Gregg's origins as a scholar because I am one of the few with close knowledge of Gregg's activities during that part of his life; however, that does not mean I was unaware of the personal characteristics that made him a terrific person as well as an excellent scholar. I can say without hesitation that those first years of my academic life at Utah were the best of my entire career. Gregg was a huge part of the reason those years were so satisfying and productive. Gregg was at the center of what became an incredible group of doctoral students at Utah during the 1980s. We formed a true research team. We worked hard on research, encouraged each other to be productive, supported each other personally, and frequently socialized together. It was during these more social times that I got to know the real Gregg behind the scholar. Gregg was always generous of heart, friendly of manner, kind of disposition, available to help anyone in need, and funny as heck (that's how we said it at Utah) at a party. It is no wonder that so many people who knew him have agreed to write remembrances of their times with him. He was a special person. I feel privileged to have known and worked with him for as long as I did.

\section{Ralph Reynolds, Professor Northern Iowa University}

Those of us at the University of Nebraska-Lincoln (UNL) recall with great pleasure that Gregg Schraw chose to begin his distinguished academic career here in our Department of 
Educational Psychology. He favored us with his service as a teacher, researcher, and advisor from 1990 until 2000, when he left UNL to join the faculty at UNLV. As is well known, Gregg's accomplishments and scholarly influence only continued to grow after his leaving Nebraska. This tribute, however, will focus primarily on Gregg's remarkable impact at UNL on his students, fellow faculty, and indeed on the qualities and character of our entire department and college.

Gregg arrived here in 1990 as a new $\mathrm{PhD}$ from the University of Utah armed with the outstanding repertoire of skills and insights that degrees in teaching, cognition, learning, and applied statistics can provide. He also arrived with a mission - making sure that high-quality cognitive and motivational research plays an important role in teaching and educational program design.

The search that led to Gregg's hiring was to fill the position previously occupied by the late John Glover, who while here in the 1980s had published 14 articles in the Journal of Educational Psychology, most coauthored with students and colleagues. John also was the Founding Editor of Educational Psychology Review. Big shoes indeed, but ones that Gregg did not hesitate to attempt to fill from the moment he accepted our job offer. It was almost instantly clear to everyone that we'd made an outstanding decision - that Gregg not only was a highly capable researcher, teacher, and mentor, but a genuinely fine person.

Building on work begun with his mentors and colleagues at Utah, Gregg almost immediately began to produce an impressive array of empirical and theoretical pieces focused on interest, metacognition, and goal orientation. Although these products clearly demonstrated his talents as a theoretician and researcher, they also were testament to his ability to share his knowledge and expertise with others, as he authored over a dozen articles with his students here in the 1990s alone. Counted in this group are many current leaders in the educational research world, individuals who not only benefited from Gregg's superb technical and theoretical skills, but from his example of how to work effectively with students and colleagues.

By mid-decade in the 1990s, Gregg's influence and collaborative style had extended to almost all of our cognition, learning, and development faculty, with significant collaborations and co-authored publications appearing on topics ranging from metacognition and goal orientation to implicit theories of reading. For my own part, I know he affected my perspectives in a most productive way, helping change my sense of what was important in educational research from a more exclusive focus on memory and cognition to one where factors such as interests, goals, and beliefs are seen as critical to student performance and outcomes. With this perspective came greater attention to student decision-making and self-regulatory processes, of students doing rather than being done to.

One clear record of Gregg's impact can be seen in the several editions of our cognition and instruction textbook. This text began its life as John Glover's and my joint venture and was coauthored with our colleague Royce Ronning. We loved working together on it and were proud of our effort. But when the tragedy of John's untimely death in late 1989 led to my taking over the leadership for this book, and when our team was reconstituted for a second edition (Bruning, Schraw, Ronning, and Glover 1995), the text clearly bore the impress of Gregg's thinking. This new edition, as we stated in our introduction, included "...two major new sections, one outlining new research on the importance of beliefs in cognition, and a second [describing] current approaches to problem solving, critical thinking, and reflective thought." As we continued (and I attribute this in great measure to Gregg), we stated that "....as cognitive psychology matures, it is moving rapidly toward an increased emphasis on the role of beliefs in guiding and motivating cognitive processes." 
The two chapters in the first of these two sections were described as "entirely new," examining motivational issues of special importance to educators. The first, "Beliefs about self," included Bandura's social cognitive theory, attribution theory, and addressed issues of student autonomy and control. The second, "Beliefs about intelligence and knowledge," was described as showing "...how beliefs about ability and the nature of knowledge are critical determinants of what students choose to do and what they achieve." Thus, Gregg's thinking not only impacted his coauthors, but through his continuing research-generated refinements up to and including a current 5th edition (Bruning, Schraw, and Norby 2011), has affected the many readers who have encountered the text in educational and cognitive psychology courses.

So that is a small glimpse of Gregg from my perspective. A superb theoretician and research designer, and a person most generous with his ideas. And an individual so easy, almost magical in hindsight to work with - someone with whom I sat for countless hours as we read troublesome sections of manuscripts and each word of our textbooks aloud. As we edited, our signals to the other for needed editorial improvements most often were just a raised eyebrow or slight change in breathing or posture.

But what perhaps is most remarkable to me is that through the many years in which we shared our work lives from when our paths first crossed in 1990, I cannot recall a single harsh word arising in our interactions, even as we sometimes disagreed. So I'll always feel that the gift of Gregg was wonderfully special for me, even as I also realize that I was not alone in my experience. All of us here at UNL know we are joined by many, many more at Utah, UNLV, and around the world in mourning his loss.

\section{Roger Bruning, Professor University of Nebraska-Lincoln}

Gregg Schraw was my colleague throughout the 1990s in the educational psychology department at the University of Nebraska-Lincoln, where he was widely appreciated as an outstanding researcher, teacher, mentor, and collaborator. Although his focus was on learning and mine on development, we shared an interest in metacognition and a concern with theoretical conceptualization, leading to collaboration on an article entitled "Metacognitive Theories" (Schraw and Moshman 1995).

Gregg and I were also regulars at the departmental Booze, News, and Reviews (BN\&R), which met late Friday afternoons at a local bar. His son Jeremy and my son Mike, who were about the same age, often accompanied us and played pool in the next room. Then we would take them to dinner (usually at Wendy's) and a movie, after which Mike often went home with Gregg and Jeremy to spend the night.

Jeremy could have stayed over at our house but Mike preferred Jeremy's because Jeremy had great toys, including an excellent assortment of G.I. Joes and Legos. Mike remembers that Jeremy also had a huge army of "beige men," though Mike was much more interested in the G.I. Joes. When Gregg and Jeremy moved to Las Vegas, Mike bought them all at a good price, which greatly enhanced his collection.

Mike also recalls that Gregg allowed them to watch Mortal Kombat, a 1995 movie based on an earlier video game, provided they agreed to fast-forward through the violent parts. Despite Gregg's theoretical commitment to promoting self-regulation, it appears he monitored this himself. According to Mike, Gregg would hang around making stupid jokes despite Jeremy's best efforts to get him out of there. 
Mortal Kombat no doubt made more money for its creators than did "Metacognitive Theories," which made no money at all for Gregg (its primary author) or me. But as of October 2016 (according to Google Scholar), "Metacognitive Theories" had been cited in over 950 articles, chapters, books, and dissertations, with new citations at a rate of about 100 per year in recent years. The article is widely seen as having helped establish a systematic conceptual framework for the study of metacognition. As for Mortal Kombat, Mike now rates the movie as "awful."

I had not been in touch with Gregg in recent years and was shocked to learn of his death. I take some solace in the fact that his work endures, as do Jeremy's G.I. Joes, which now reside in our basement.

\section{David Moshman, Professor Emeritus University of Nebraska-Lincoln}

I first met Gregg Schraw in Fall 1990. I was returning to the University of Nebraska as a doctoral student and Gregg was a brand-new assistant professor. I enrolled in Gregg's problem solving course and was immediately impressed with his genuineness, rigor, and work ethic. The work ethic was also reflected in the amount of time he spent in his office. I can still picture him with his back to the office door, facing out the window while he typed away. Gregg was extremely productive during his time at UNL. Some of his drive simply came from a love and passion about what he was doing. But I can also tell you that much of that drive came from what many of us have experienced as new assistant professors. He was nervous about getting tenure and wanted to make sure he had enough to show for his time. Having colleagues such as Roger Bruning, Ken Kiewra, and Dave Moshman was both a blessing and also set a pretty high bar for expected productivity.

Gregg and I attended the annual meeting of the Mid-Western Educational Research Association in Chicago in October 1990. Like most grad students, I was short on travel funds. Gregg graciously offered to share a room with me and then paid for it. But more than this act of financial generosity (which Gregg admonished me to pay it forward), I fondly recall our conversations. He expressed his anxiety about his new position. He talked about the pressure of trying to get tenure while also spending time with his family. I was struck by his honesty and found this to be prophetic in terms of my own challenges a few years later. I'd like to think Gregg and I bonded during these few days. That bond kept us friends and colleagues for over twenty years.

Gregg and I succeeded Mike Royer as editors of the Current Perspectives on Cognition, Learning, and Instruction book series from 2006 to 2013. Besides the first publication we coauthored (Robinson and Schraw 1994), we also had a book chapter (Robinson, Levin, Graham, Schraw, Fuchs, and Vaughn, in press) and an article that emerged from a meeting hosted at the Meadows Center for Preventing Educational Risk at the University of Texas to discuss when recommendations for practice are appropriate (Robinson, Levin, Schraw, Patall, and Hunt 2013).

Our last "true" time spent together was when we attended an AACTE (American Association of Colleges for Teacher Education) meeting in Spring 2013 in Orlando, Florida (I was Director of the School of Education at Colorado State and Gregg was Associate Dean of Administrative Affairs and Research at UNLV). Hanging out in a hotel room, much like we did back at the Bismarck Hotel in 1990, we discussed our careers and goals. Gregg wanted to be a journal editor. He wanted to be a dean. He spoke of the things he wanted to do before 
retiring. His passion and energy were the same as they had been 23 years earlier. Gregg leaves in his wake countless people who he affected in a positive way. I am fortunate to be one of those people.

\section{Daniel H. Robinson, Director of Research and Measurement University of Texas-Austin}

I first met Gregg when he interviewed for the position at the University of NebraskaLincoln (UNL). He came to UNL full of energy, confidence, and a quick smile. These personal characteristics remained evident through our overlapping early years in Lincoln.

Gregg demonstrated a tenacious work ethic. He was compelled to ask and answer theoretically grounded questions. He brought keen analytical skills to the design and analyses of research. His writing ability was enviable in approach, style, and pace. Gregg's numerous contributions maintain consistent ongoing citations. This pattern, as well as a recent resurgence in citations to some of his earlier metacognition research, provides evidence that his body of research will continue to have far reaching effects on the field for years to come.

I am grateful for the mentors that introduced me to this work we do and for the lessons I learned from Gregg's model. Most of Gregg's publications were collaborative efforts and he collaborated with dozens of students over his career. As a mentor, Gregg modeled hard work, persistence, patience, and a love for the quest for answers; all characteristics I strive to emulate with my own students.

Gregg's legacy is not only the numerous articles, chapters, books, products, and awards but also the passion and approach to research that he instilled in us as his students and collaborators. It will live on in the way we model the quest for new questions and their answers to our students and our students' students.

\section{Rayne Sperling, Associate Professor The Pennsylvania State University}

Gregg Schraw was, quite simply, the best mentor a doctoral student could ever hope to have. As an instructor, he taught me everything there was to learn about cognition, learning, and motivation (circa 1999) and challenged me to move beyond, to think in new ways, and to pursue strange, often controversial research questions that might bring new perspective to the field of educational psychology.

So many classes I took from Gregg were critical for my development as a scholar, but the pivotal course was called "Beliefs and Cognition." As we explored both current thought, and long-standing seminal theories, I found myself questioning many key constructs and frameworks. Two examples remain etched in my memory. First, while studying goal orientation theory, I kept thinking something must be very wrong with me because I fit the profile of a performance goal student. The research seemed to indicate that this was not a useful orientation for a serious doctoral student, yet I felt very motivated and was doing well. I believed that students, ideally, should be high in both performance and mastery goals. With no small degree of trepidation, I confessed to Gregg, and with my arms crossed to form quadrants, I announced that "high, high is the optimal type of motivation." I was hooked on motivation scholarship as a career path. Many great discussions followed.

Second, I questioned self-determination theory's emphasis on autonomy. I thought that people had very differing degrees of autonomy need and that the extent to which autonomy 
support (i.e., choice) benefited motivation and learning was contingent upon a myriad of contextual factors; prior knowledge, consequences of choice, number and disparity of preference for options, and cultural background among them. Gregg supported me as I set out to use quasi-experimental (and qualitative) methods to better understand the subtleties of giving choice as a means to increase motivation and learning.

During the eight years we worked together on research, there were many presentations at AERA. Deci and Ryan nearly always came to our presentations, and having Gregg at my side helped lessen the anxiety I was feeling as a graduate student disputing key tenets of their theory. All three senior researchers were always kind and supportive, and on one occasion I was told that they would have to consider my research as they moved ahead with their theory. This was a highlight of my graduate experience. Five journal articles followed.

Gregg's confidence in me and steady, supportive guidance provided the self-efficacy boost I needed in order to believe in myself as a scholar with something to say. As co-chair of my dissertation, mentor throughout my career, and dear friend always, Gregg was a strong, positive force in my life. Now, my own doc students tell me I am a wonderful, supportive mentor, and I always tell them, "I am just doing what I was taught; mentoring as I was mentored." Gregg taught me this too. His mentoring continues with the students he mentored (and there are a lot of us) who now have students of our own.

\section{Terri Flowerday, Professor}

University of New Mexico

August 2005: Onions and collaboration.

"I love fried onions!" A strange confession to be hearing at 6:00 AM at the breakfast table. Gregg continued, "Lori's mom makes the best fried onions." The air in my little house in Logan was choked with the smell of my attempt to follow the recipe of Gregg's mother in law. A thought flashed across my mind... How can someone with such clarity of thought and deep knowledge have such dubious preferences in food?

Gregg and Lori used my Logan, Utah, bungalow as midpoint stopover on their biannual trip between Las Vegas heat and the crisp Canadian Rockies. Gregg's influence in my career extended beyond mentoring me as a graduate student to collaboration in my first position at Utah State. That morning, we escaped the onion haze in my kitchen with the usual hike. Topic of conversation: finalizing theoretical framework of a study write-up and planning the extension study. We always worked on something. Typical Gregg. Always thinking, always productive.

\section{Gregg worked hard}

April 1998: Eggs and mentoring

"This is the best breakfast in San Diego." 6:00 AM. I was skeptical. Walking up the greasy alley, the Gaslamp district of San Diego did nothing to bolster my confidence in his enthusiasm. Gregg was "showing me the ropes" at AERA. The breakfast was a cheap adventure. The quality of the food faded into insignificance as we talked.

The conversation shifted to presenting at AERA. My 35 slides presentation represented the polar opposite of Gregg's presentation the day before which contained zero slides, a 3 point outline, and 2 overhead transparencies with data tables "just in case." The data tables never 
made it onto the projector. The entire room buzzed with conversation about extending theory and application for kids in schools. "How did you do that?" I asked over my blackened egg.

"Talk about the big, important ideas and what they mean. You can tell people what you did, why you did it, and what you found, but always come back to the big ideas and what they mean."

Thirty-five slides became seven, a large room full of people were enjoyed a meaningful conversation instead of a paralyzing parade of data tables. Of course, Gregg was there. He was always there.

Gregg showed me that simple is better.

"Use short sentences."

"Use the simpler words."

"We need to make this flow better."

"Show them the essence of the theoretical framework."

Gregg mentored well.

July 1997: Apples and enthusiasm.

5:00 PM. Bancroft Hall, University of Nebraska. "This is a good apple!" I tried not to stare as the core grew impossibly thin, and then was gone. Wrapping up our second formal mentoring meeting, Gregg dropped the apple stem in the trash. I smiled inside as we locked up the office. I was going to like working with someone who would eat ALL of an apple.

We walked down the steps of Bancroft Hall. "I am so lucky!" Gregg continued, "I get to work with grad students on important ideas. I get paid to do research and write... and my kids are doing great."

"I am so lucky." There it was. Perhaps the most often repeated phrase in Gregg's conversation. "I am so lucky." Gregg was infectiously positive.

"I'm so lucky. I get to work with great grad students."

"I'm so lucky. The kids are doing great."

"I'm so lucky. Lori is awesome."

"I'm so lucky. Life is great."

Gregg inspired his friends.

The smell of onions eventually cleared from my kitchen in Logan. The indigestion from whatever I ate in that alleyway cafe passed in only a day. The apple core moment only comes back to me when I am tempted to just finish my apple off. As Gregg would have said, "It turns out" that the food really did not matter... but my time with Gregg. Profound.

Thinking back, I have to agree with Gregg. I am so lucky.

\section{Steve Lehman, CEO}

EdSolutions LLC

As a graduate student at the University of Nebraska, I had the good fortune of interacting with Gregg Schraw almost daily. Unlike other students benefiting from Gregg's mentorship and instruction, I was not studying cognition and learning but rather quantitative methods. Yet, Gregg met with me weekly just as he did his own advisees. Gregg's mentorship of others in related yet distinct fields reflects his generosity of his limited time and immense skills.

During meetings with Gregg, I interacted with an enthusiastic partner who urged those he worked with to think deeply and to make a difference. Gregg's big-heartedness reflected in that huge smile made one excited for research meetings. His kindness was coupled with honesty; Gregg could provide critical, yet necessary, feedback in a fair and caring manner. Gregg 
beautifully balanced challenging your ideas with celebrating your progress and the value you brought to a project. When I conduct research meetings with my students, I try to emulate Gregg to encourage and scaffold learning as he did.

Gregg's advice about career and life in general guided me then and sustain me today. His constancy and commitment to student development made me realize early on that I was working with someone who would have a tremendous impact on my life. We can all envision the handful of people in our professional lives who made a powerful, positive impact. For me and so many others, Gregg's contribution to our training and career is unparalleled. I feel a great sense of loss of a teacher, mentor, and friend. Yet, I feel fortunate that I can still hear his footsteps coming up the marble staircase in Bancroft Hall as I sit outside his office waiting for our weekly meeting.

\section{Sara Finney, Professor \\ James Madison University}

I recollect that I first met Gregg Schraw in 1991 in a hallway of the old Bismarck Hotel in Chicago, home at that time to the annual fall meeting of the Mid-Western Educational Research Association. Perhaps because we were very new in our respective academic careers, we struck up a friendship that, at least in those early years, revolved around our mutual anxieties about life on the tenure track. We generally saw one another at MWERA in the fall and again at AERA in the spring, with occasional phone calls and e-mails in between.

A few memories come readily to mind when I think of Gregg. It was quickly apparent that he was going to be a "big deal" in the field, but he never had an ego about it. While he took his work very seriously, he always appeared to have great fun in carrying it out - evidenced by the wonderful smile that he wore when he described his research or the successes of his students.

Some years ago, my students and I did a small study of faculty productivity in educational psychology and Gregg was revealed to be among the very top "producers" of published papers. He later told me that his dean had awarded him with a nice salary adjustment as a consequence of that paper. In return, Gregg welcomed my family and me - and our dog - into his home for an overnight stay as we drove west to Portland, Oregon, for a year's sabbatical leave. He could not have been a more gracious and accommodating host. I am pretty sure my boys would have been happy spending the rest of the summer with Gregg and his son, Jeremy!

In 2009, I organized a research conference for graduate students at my university and invited Gregg to serve as keynote speaker. Unfortunately, I never got to hear his talk because I was awaiting back surgery and spending my days prone on the floor. At the conclusion of the conference, my graduate students collected Gregg and drove to my house where we all spent a lovely evening discussing the day's events. Although my students were a bit intimidated at the prospect of hosting such a well-known educational psychologist, their apprehensions were quickly eased by Gregg's warmth, humor, and sincere interest in the work that each of them was doing. Learning that Gregg had grown up in the neighboring town of Sycamore, Illinois, confirmed for all that he was a regular guy.

Upon moving to West Virginia University to become Associate Dean for Research, I called Gregg - who was serving in the same role at UNLV - to pick his brain and get some advice about how to establish and run a college research office. Once again, he was so generous and encouraging, and sent me many helpful materials - even links to several instructional videos that he had created! Not long after, he sent along a manuscript he had been developing and asked if I'd like to work with him to finish it. But, when I read it, I saw that the work was 
already complete - there was nothing substantive that I could add. And so, I declined, missing an opportunity to be among the dozens of collaborators with whom Gregg generously shared his ideas and intellect throughout his substantial body of published work.

But much more than that missed opportunity, I will miss hanging out with Gregg at AERA and those times when we would enjoy a few beers at social hours, dine out together with our wives, and share stories of our kids' (now young adults) successes. I will miss very much his kindness, generosity, and friendship.

\section{Cecil Smith, Professor West Virginia University}

"You, sir, are a gentleman and a scholar!" In my formative years, my friends and I would facetiously toss out that "compliment" when a competitor would throw a wobbly pass for an interception, miss a two-foot putt, or mistakenly "Trump" a winning trick in bridge. Now, eons later, with Gregg's passing, the intended interpretation of the expression has resonance. In our academic field of educational psychology, there surely are talented researchers, just as there are exceptionally decent human beings. Yet, rarely can one point to an individual whose life fully exhibited both of those exemplary characteristics - other than Gregg Schraw, that is. Impeccably crafted, masterfully articulated, empirical research studies: that was one side of Gregg's calling card. Unabashedly outgoing, genuinely warm and empathetic in his demeanor, principled to the $n$th degree: that was the other side. I am privileged to claim Gregg as both a professional colleague and a personal acquaintance. So, in all sincerity, and with the utmost admiration, let it be stated emphatically: Gregg Schraw was truly a gentleman and a scholar!

\section{Joel R. Levin, Professor Emeritus University of Arizona}

Most of us can look back on our life and identify some pivotal moments where our trajectory was forever altered. For me, it was in the mid-90s at the University of NebraskaLincoln Teachers College. As a high school science teacher returning to graduate school, I had just described my experience and interests to David Brooks. He told me that I need to introduce myself to Gregg Schraw. I have been the beneficiary of a lot of good advice in my life, but this nugget proved to be the most valuable.

I took one class from Gregg and was so impressed that I vowed to take every class I could from him in subsequent terms. Gregg was that rare scholar who could bridge the gap between research and practice in a manner that indicated he understood the constraints that teachers often faced. He was incredibly well prepared for each class. I will never forget walking into class and viewing a large concept map written on the board. An engaging class discussion would be guided by this construction for the next $2 \mathrm{~h}$.

I found Gregg to be so relatable and knowledgeable that I sought out his service on my dissertation committee. This was a bit of a stretch as my area was educational technology, not psychology. Gregg was not known for his tech savviness (I am hunting and pecking the keyboard in his honor). In spite of his substantial advising load and technology aversion, he joined my committee. He helped me develop a research program that addressed issues of learning with the support of technology rather than the reverse. 
I was thrilled when he decided to join the faculty at our current institution, the University of Nevada, Las Vegas. In retrospect, his guidance during those years at Nebraska and early years at UNLV was key to any subsequent scholarly and mentoring achievements I can claim.

While my memories of Gregg as a scholar, teacher, and mentor have profoundly shaped my professional career, it is the time I spent with him outside of the university that I will miss most. He truly loved life and was a delight to be around. His children were a few years older than mine, so I was forever quizzing him about parenting. We both remained puzzled as to how to convince middle school boys the importance of bathing without the threat of violence.

Aside from my anger for a life to be cut unfairly short, I take some solace in the fact that in the 20 years I knew Gregg, he led a fulfilling life surrounded by friends and family. He was able to watch his children mature into successful and dynamic adults. He was able to travel the world and sip some good wine along the way. All of this, he enjoyed with his best friend Lori at his side.

\section{Kendall Hartley, Associate Dean Graduate College University of Nevada, Las Vegas}

I met Gregory Schraw on April 20, 2003, in Chicago, IL-his hometown. I was participating in AERA's Division C Graduate Student Mentoring program, and Gregg was my mentor. I was so nervous about meeting such a prolific scholar that I could barely introduce myself when we first met. This is to be expected - Gregg was consistently ranked as one of the most productive scholars in educational psychology each year over the past 25 years. As a graduate student, I had cited a significant amount of his work and used several of the instruments he had developed over his career for my own research. Of course I was nervous! But it wasn't his productivity, in depth knowledge of statistics, methodologically rigorous work, or brilliant mind that impressed me the most. What impressed me about Gregg was that he was such a nice guy. Gregg was also down to earth, humble, and had a great sense of humor. At AERA that year, I also met Gregg's wife, Lori-a fellow Canadian. I was sold. Having never even visited Las Vegas, the plan was set-I would begin my career at UNLV and join a wonderful group of scholars the following year.

Gregg's mentoring did not end at AERA. When I joined the faculty at UNLV in 2004, Gregg continued to provide sage advice on how to navigate the complex waters of life as a new faculty member. He shared his teaching materials, provided guidance on research designs and how to respond to reviewers' criticisms, and gave me opportunities to conduct evaluation research in the schools. But one of the most important lessons that I learned from Gregg was that life is not all about work. Gregg, Lori, Michael (my husband), and I spent many hours hiking in Red Rock Canyon or golfing on the various greens in Las Vegas. And while Michael and Lori ran $5 \mathrm{~km}$ races, Gregg and I walked the shorter $1 \mathrm{~km}$ distance. During our walks, we talked about our plans for the future - a future, sadly, that Gregg will never see. We also spent Thanksgiving (both Canadian and American) together with our growing families and watched countless NHL hockey games. Gregg loved NHL hockey. He may have cheered for the wrong team, but at least his all-time favorite hockey player was Jean Béliveau.

It's difficult to imagine that new graduate students and faculty will not have the opportunity to learn from one of the greatest. He has mentored so many. The world is darker now that he is gone, but I will continue to teach my graduate students the important lessons he taught me so that his light shines on. 


\section{Krista Muis, Associate Professor and Canada Research Chair McGill University}

Gregg was an inspiration to me in many ways. His work in so many areas with a wide range of collaborators has become a model for my scholarship. Gregg's curiosity about situations and desire to gather evidence to empirically support explanations was not limited to a specific line of research rather to interesting events or circumstances. As he talked about his research ranging from student procrastination to the misalignment between teachers' perceptions and practices, he made it apparent that it was interesting questions rather than the content that drove his research and productivity. As a graduate student I was amused when Gregg shared his great fondness of Lipsey's (1989) Design Sensitivity, as he just seemed so committed and passionate about doing good research and appreciated the efforts of others embracing the same goals. I feel very fortunate to have been part of one of Gregg's explorations of the human condition in our research on behaviors and motivation associated with student cheating. He made the research enjoyable and exciting as we explored new ideas and learned from our research new explanations, a model that has inspired and motivated me to use my imagination and creativity to guide my research as he so effortlessly did. In addition to being a great researcher with a diversity of interests, Gregg was a wonderful person. I so enjoyed conversations with him and his passion and enjoyment of life. I will miss him very much. He has touched the lives of many and inspired all of us to ask interesting questions and then find the answers.

\section{Louis Nadelson, Instructor of Statistics Colorado Mesa University}

Gregg Schraw was an amazing human being — both professionally and personally. His research in the field of epistemic cognition is both inspirational and enduring. In particular, he has helped to shape how we think about teacher beliefs in the context of classroom interactions. As well as being an insightful researcher, Gregg was a very kind, encouraging, and generous mentor for new academics in the field. I experienced his support on many occasions from his quick responses to e-mail queries from "down under" to his enthusiastic support for my publishing ideas. I first met Gregg on a visit to the USA in 2009. At the time, Gregg and I were planning to edit a book together and the visit supported the final planning stages. Academia can be a pretty daunting place for early career researchers - but along the way people who genuinely take an interest and take time to support others' work can make this process easier and more rewarding. Gregg made a genuine difference to my career and those of others. I am really grateful to have had the opportunity to work with Gregg as a mentor - although I doubt he ever thought of himself that way. He demonstrated a humility that was refreshing and generative. His generosity of spirit, encouragement, and plain kindness allowed others to grow and prosper both personally and intellectually. He invited the contributions of others to a field he had significantly defined and enabled true synergies to develop. Although I will miss Gregg's friendship and professionalism, I know he will live on in both the field he has helped to create and nurture and in the lives of the researchers he has supported along the way. I think that's what you might call "immortality."

\section{Joann Lunn, Professor \\ Queensland University of Technology, Brisbane, Australia}

I shared the high honor of being among one of Gregg's final students. Alas, I only knew him for six short years. Nevertheless, it is no hyperbole when I say that I will remember those 
as among the best six years of my life. When I initially approached Gregg about the possibility of him serving as my dissertation advisor, he did not turn me down but instead said to me, "I think your idea has merit. Why don't you do some more reading on self-regulated learning, flesh it out a bit more specifically, and come back to me then... By the way, I don't know you well but the faculty who know you best speak highly of you... I know you'll get far if you want." What a kind and compassionate mentor, Gregg. Even when providing criticism and constructive feedback, he did it in a way that will inspire you to challenge your current way of thinking and to continuously improve your understanding of the world around you. When he finally agreed to be my advisor, Gregg clearly and succinctly explained his approach to mentorship. He shared that he is not much for giving compliments, not because he was not proud of you but because he feared that by giving too many of them, it would make you lazy and complacent. Compliments to Gregg were to be always genuine, sincere, and truly earned, which encouraged his students to perennially try harder to achieve their goals. When providing advice, Gregg once said, "You retain the 'executive veto' to ignore my advice with no hard feelings on my part; however, the consequences of your actions will be yours alone to bear if you do." This instilled autonomy, agency, and empowered me to be self-sufficient.

When I last saw Gregg (December 2015), he asked if he could hug me, which was all the more meaningful because he was not much for demonstrating physical affection. I will always remember that, in spite of his frail body, I have never felt a warmer, more invigorating, and loving embrace, as if his spirit was saying, "This disease will not dampen my strength or change the essence of my being." As we embraced, he said, "I am proud of the work you have done and all you've accomplished so far... I know you will go farther still." Thank you for everything Gregg. I will always fondly remember the all too brief time we spent together as well as your laugher, joy, passion, vitality, humility, and keen intellect. Cheers to you, Gregg Schraw!

\section{Antonio Gutierrez, Assistant Professor Georgia Southern University}

As a prolific scholar, Dr. Gregory Schraw will be appropriately remembered for his professional contributions. However, my lasting thoughts will be of his diverse intellectual capacity and the positive energy he conveyed. Beyond scholarly endeavors, Gregg actively pursued opportunities to put concepts into practice through evaluation work, contributing to test design and development, and advising on assessment policy and practice at a state and national level. He approached these activities with a combination of excitement and humility as he considered these learning opportunities. It would be difficult to find a better colleague.

Gregg also enjoyed communing with nature. On most Saturdays for the last eight years, we would drive out to Red Rock Conversation Area on the west edge of Las Vegas to run/walk trails. At the outset and conclusion of these activities, we would discuss current research projects, publications, and some of the applied work that we shared. This frequently led to us talking more and exercising somewhat less than we had planned, but it always spurred me to think about research and interdisciplinary collaboration opportunities.

Even facing a terminal diagnosis, Gregg's attitude remained consistently positive. He was looking forward to getting back to teaching at UNLV and to the city's expansion NHL team; no doubt excited to be able to see his Chicago Blackhawks and his wife's Calgary Flames when they visited. And as a Chicago Cubs fan, he thought that this was finally their year. As tribute 
to him, I hope it is, but would prefer that he was here to experience it and to share that excitement as a fan and a friend.

\section{Chad W. Buckendahl, Partner ACS Ventures, LLC}

I arrived at the hospital in September 2015. I went up the elevator and down the corridor to Gregg's room not knowing what to expect. He had lost over $50 \mathrm{lbs}$., or nearly $25 \%$ of his body weight, as a result of cancer, which had quickly spread throughout his body. As I entered the room, he greeted me by name, face beaming with a smile. I was pleased to see him, while at the same time saddened to see the toll his body had taken. And, I knew he was in a battle for his life that many before him had lost. Nonetheless, his spirit remained intact, unscathed by the challenge before him, and at some level emboldened to emerge victorious.

Over the next couple of days, I made various trips to see him at the hospital. Before my visit, I last saw him in person six months earlier when we had met for burgers and beers at AERA, our annual ritual. We picked up where we had left off. We talked about everything from family to work, politics to real estate, and environmental science to the Cubs' chances in playoffs (Gregg was from Chicago and big baseball fan). Two things stood out from our conversations over those couple of days. First, his deep love for his wife Lori and his children Jeremy, Jacqueline, and Rob. As a graduate student, I remember him talking about his kids. Now, he was elated by their successes and the impending arrival of his and Lori's first grandchild. Nothing seemed to bring him more joy than seeing his kids happy. Second, was his desire to live, which was apparent when he discussed his chemotherapy. Gregg is wellknown professionally as a top-notch quantitative researcher. However, he is also an accomplished qualitative researcher. He basically laid out his experience with chemotherapy in a phenomenology, a type study in which a person describes a lived experience. He described the waiting room and the body language of those waiting to receive treatment. When one loses the will to live in the face of death, it cannot be hidden. He could see that in the eyes of some fellow patients. Gregg had an immensely strong will to live. He wanted to spend more time with family and friends. He wanted to return to his work. He was realistic that his time was limited, but he expected to savor life a bit longer. Shortly after my visit, I realized that Gregg had beaten cancer. It was taking his body, but not his soul. Gregg had a tremendous impact on those he interacted with, both personally and professionally. He will be truly missed.

\section{Matthew T. McCrudden, Associate Professor Victoria University of Wellington, New Zealand}

"The world is somehow different." These are the words we uttered as we tried to make sense of the news that Gregg had died much sooner than we anticipated. As I write, it seems crazy now to say that we were shocked that Gregg had died only days after entering hospice. I mean we had just chatted with him three days before I got the call, so I did not expect it even though I had been dreading the day.

Because of his illness, many people were unable to see or speak with Gregg over the last 18 months, and I know many are writing about his amazing talents as a mentor and scholar (which he was to his core and continued to be to the end), so I have decided to include some description and thoughts regarding the last part of Gregg's life. This will be hard, and my fear is his death is too raw for me to do him justice, but I will try. Much of this time was heart- 
wrenching but, more importantly, it was also beautiful. I witnessed this beauty in a number of ways including talks about his childhood, visits with several of the former students he had mentored, time spent with his children and new granddaughter, and the way he deeply appreciated the love and unwavering care he received from his wife, Lori.

He told me it brought him great peace to know that his kids were debt-free, had happy marriages, and much to look forward to in the future, and he remarked on this quite often. The pride he had in the accomplishments of his children was written all over his face when he spoke of them. I got to be a part of some of those family gatherings - they were lively and sweet, especially the ray of sunshine Gregg and Lori's new granddaughter brought to the family.

I am happy to say that Gregg's appetite remained strong throughout this time, and he frequently had specific cravings: Panda Express, malted milkshakes, and deep-dish pizza. When you love someone, and they are sick, you often do not know how or what to do to be helpful in ways that are meaningful. But I can cook a meal, and it gave me great pleasure that he often asked for my potato-leek soup. There were also a few "civilized meals" delivered to Gregg during his many hospital visits, which included cloth napkins, flowers, proper bowls, and silverware lending some dignity to an otherwise unworthy situation.

There were a handful of peaceful, breezy nights sitting by my pool surrounded by close friends and family from near and far, who came in town to be with Gregg and Lori. In one way or another, there was always laughter along with tears most of these nights. So lovely, were Gregg's brother Tom's almost weekly visits to cook, care for Gregg, and give Lori a brief break.

I will always cherish the fast friendship that Gregg and my wife, Milly, developed over sweet chats about the poetry they loved and the importance of the writing life. I wonder who knows that Gregg wrote every day that he could - poetry not least among his writings.

I think what I find most beautiful about this time was the almost untiring hope that Gregg shared and his unwavering gratitude for the moments he did have. "It is a great day to be alive!" He would often say and he would always, always stop, give a kiss, and thank you for whatever small thing you had done.

"The world is somehow different." It is. Although there is a feeling that a gaping hole has been left after losing this amazing human being, I know that his love and legacy, what we all do in our words and actions next, will help to fill it.

I located a short poem that was written by Gregg and published in the Atlanta Review (2001). Thank you to Dr. Mark Halliday who sent the poem to me and quoted Gregg's poem in an essay he had written entitled: The Problem of Fair Reading (2001) in the Cimarron Review. Halliday's quote reads

Someone with the fabulous name G. J. Schraw has a short poem called "Titanic" in Atlanta Review. I think, and am glad to think, that this poem is too purely pessimistic, and I imagine G. J. Schraw knows this, and would agree that the poem reflects a mood. As I leave the Bryn Mawr café, knowing I have surely overlooked some good poems in Atlanta Review, I'm not depressed, but Schraw's mood doesn't seem utterly alien. Here is "Titanic":

Not even a huge poem such as this one can carry enough lifeboats to save its crew.

So the voice sinks slowly into the depths of silence.

Everything we might have said to save ourselves is lost.

\section{Lisa Bendixen, Associate Professor \\ University of Nevada-Las Vegas}




\section{References}

Bruning, R., Schraw, G., Ronning, R., \& Glover, J. (1995). Cognitive psychology and instruction (2nd ed.). New York: Prentice-Hall Publishing Company.

Bruning, R., Schraw, G., \& Norby, M. (2011). Cognitive psychology and instruction (5th ed.). New York: Prentice-Hall Publishing Company.

Burbules, N. C., Schraw, G., \& Trathen, W. (1989). Metaphor, idiom, and figuration. Metaphor and Symbolic Activity, 2, 93-110.

McCrudden, M. T., \& Schraw, G. (2007). Relevance and goal-focusing in text processing. Educational Psychology Review, 19, 113-139.

Nietfeld, J. L., \& Schraw, G. (2002). The role of knowledge and strategy training on monitoring accuracy. Journal of Educational Research, 95, 134-142.

Olafson, L. J., \& Schraw, G. (2006). Teachers' beliefs and practices within and across domains. International Journal of Educational Research, 45, 71-84.

Robinson, D. H., Levin, J. R., Graham, S., Schraw, G., Fuchs, L. S., \& Vaughn, S. R. (2016). Improving the credibility of educational intervention research. In A. M. O'Donnell (Ed.), Handbook of educational psychology. Oxford: Oxford University Press.

Robinson, D. H., Levin, J. R., Schraw, G., Patall, E. R., \& Hunt, E. (2013). On going (way) beyond one's data: a proposal to restrict recommendations for practice in primary educational research journals. Educational Psychology Review, 25, 291-302.

Robinson, D. H., \& Schraw, G. (1994). Computational efficiency through visual argument: do graphic organizers communicate relations in text too effectively? Contemporary Educational Psychology, 19, 399-415.

Schraw, G. (1995). Components of metaphoric processing. Journal of Psycholinguistic Research, 24, $23-38$.

Schraw, G. (2005). An interview with K. Anders Ericsson. Educational Psychology Review, 17, 389-412.

Schraw, G. (2009). A conceptual analysis of five measures of metacognitive monitoring. Metacognition and Learning, 4, 33-45.

Schraw, G., Bruning, R., \& Svoboda, C. (1995a). Sources of situational interest. Journal of Reading Behavior, 27, 1-18.

Schraw, G., \& Dennison, R. S. (1994a). Assessing metacognitive awareness. Contemporary Educational Psychology, 19, 460-475.

Schraw, G., \& Dennison, R. S. (1994b). Effects of task-driven interest on recall of text. Journal of Reading Behavior, 26, 1-18.

Schraw, G., Dunkle, M. E., \& Bendixen, L. (1995b). Cognitive processes in well-defined and ill-defined problem solving. Applied Cognitive Psychology, 9, 1-16.

Schraw, G., Flowerday, T., \& Lehman, S. (2001). Promoting situational interest in the classroom. Educational Psychology Review, 13, 211-224.

Schraw, G., \& Lehman, S. (2001). Situational interest: a review of the literature and directions for future research. Educational Psychology Review, 13, 23-52.

Schraw, G., McCrudden, M. T., \& Robinson, D. (Eds.) (2013). Learning through visual displays. Charlotte, NC: Information Age Publishing.

Schraw, G., \& Moshman, D. (1995). Metacognitive theories. Educational Psychology Review, 7, 351-371.

Schraw, G., Trathen, W., Reynolds, R. E., \& Lapan, R. T. (1988). Preferences for idioms: restrictions due to lexicalization and familiarity. Journal of Psycholinguistic Research, 17, 413-424.

Schraw, G., Wadkins, T., \& Olafson, L. J. (2007). Doing the things we do: a grounded theory of academic procrastination. Journal of Educational Psychology, 99, 12-25.

Wade, S. E., Trathen, W., \& Schraw, G. (1990). An analysis of spontaneous study strategies. Reading Research Quarterly, 25, 147-166. 